\title{
İran'da Toplumsal Gerçeklik Ve Sinema İlişkisi Üzerine Dönemsel Bir Karşılaştırma: Sohrab Şehide Sales'in “Cansız Tabiat” Ve Mecid Mecidi'nin “Serçelerin Şarkısı”
}

\author{
Aznavur Demirpolat a, b, Esma Şener
}

\section{Özet}

Sinema sanatı, diğer ülkelerde olduğu gibi İran'da da siyasal, toplumsal ve kültürel değişimlerden etkilenmiş ve bu doğrultuda şekillenmiştir. Doğası gereği içinde bulunduğu dönemin şartlarına tanıklık eden sinema; İran'ın sosyal, siyasal, ekonomik ve kültürel yapısını geniş kitlelere ulaştırır. Bu bağlamda sinema filmleri; belli bir dönemin toplumsal ve siyasal yapısını kavrayabilmek ve söz konusu döneme dair çıkarımlarda bulunabilmek adına, referans olarak başvurulabilecek üretimlerdir. Bu çalışmada; İran'da toplumsal yaşam kadar kültürel üretim açısından da bir dönüm noktası olan İslam Devrimi'nin gerçekleştiği 1979 yılı öncesi ve sonrası döneminin sosyal ve siyasal yapısındaki benzerlikler ve farklılıkların sinema üzerinden incelenmesi amaçlanmıştır. Bu amaç doğrultusunda; İran sinemasının önemli temsilcilerinden Sohrab Şehide Sales'in “Cansız Tabiat” (1975) adlı filmi ile Mecid Mecidi'nin “Serçelerin Şarkısı” (2008) filmi incelemeye esas alınmıştır. Üretimlerini farklı dönemlerde gerçekleşmiş bu iki yönetmen de; filmlerinde dönemlerinin toplumsal gerçeklerini, İran'ın geleneksel aile yapısını, sosyal yaşantısını, kadın sorunlarını, siyasi sorunları, yoksulluğu ve işsizlik problemini konu edinmiştir. Bu bakımdan "Cansız Tabiat" ve "Serçelerin Şarkısı" ele aldıkları konular üzerinden bize dönemin toplumsal, siyasal ve ekonomik yapısının analizine imkân veren filmlerdir. Çalışma kapsamında, filmler, arasındaki benzerlikler ve farklılıklar bakımından karşılaştırılacak ve bu doğrultuda, her iki filmin çekildiği dönemin toplumsal ve siyasal yapısına yönelik bir değerlendirilme yapilacaktır.
Anahtar Kelimeler

Reform

İran Sineması

Sohrab Şehide Sales

Mecid Mecidi

Makale Hakkında

Geliş Tarihi: 25.06.2020

Kabul Tarihi: 01.09.2020

Doi: $10.18026 /$ cbayarsos.758149

\section{A Periodic Comparison on the Relationship Between Social Reality and Cinema in Iran: Sohrab Şehide Sales' "The Living Nature" and Mecid Mecidi's "The Song of Sparrows"}

\begin{abstract}
The art of cinema in Iran, just as in other countries, has been affected by political, social and cultural changes and thus has been shaped accordingly. Because of its nature, cinema witnessing the conditions of its time conveys the social, political, economic and cultural structure of Iran to large masses. Cinema films, in this context, are the productions that can be used as a reference to understand the social and political structure of a certain period and to make inferences about that period. In this study, the aim is to examine the similarities and differences in the social and political structure of the Iranian society by taking into account the films that are produced in two different periods, before and after Islamic Revolution in 1979 , which is a turning point in terms of cultural production as well as social life of Iran. In accordance with this purpose, in this study, Sohrab Şehide Sales, who is one of the important representatives of Iranian cinema', his film "Lifeless Nature" (1975) and Mecid Mecidi's "Song of Sparrows" (2008) has been examined. These two directors, whose productions took place in different periods, focused on such issues as the social realities of their times, the traditional family structure of Iran, its social life, women's problems, political problems, poverty and unemployment. In this respect, both "Lifeless Nature" and "The Song of Sparrows" are the films that allow us the analysis of the social, political and economic structure of the period through the topics they dealt with. Within the scope of the study, films will be compared in terms of similarities and differences between them and also an evaluation
\end{abstract}

Keywords

Reform

Iranian Cinema

Sohrab Şehide Sales

Mecid Mecidi

About Article

Received: 25.06.2020

Accepted: 01.09.2020

Doi: 10.18026/cbayarsos.758149

a İletişim Yazarı: a.demirpolat@comu.edu.tr

b Dr. Öğr. Üyesi. Çanakkale Onsekiz Mart Üniversitesi, Fen-Edebiyat Fakültesi, Sosyoloji Bölümü Sosyal Bilimler Enstitüsü. ORCID: 0000-0002-9341-0476

c Çanakkale Onsekiz Mart Üniversitesi Sosyal Bilimler Enstitüsü, Bölgesel Araştırmalar (Ortadoğu Araştırmaları), seneresma94@gmail.com ORCID: 0000-0003-1395-1801 


\section{Giriş}

İran sineması; sosyal yaşamın, siyasi ideolojinin, ekonomik koşulların ve kültürel kodların etkisinde kendini inşa etmiştir. İran'ın içinde bulunduğu koşulların bir ürünü olan sinema, birçok ulusal sinema örneğinde olduğu gibi; toplumsal, siyasal, ekonomik ve kültürel unsurları beyaz perdeye taşımıştır. Sinema ve toplumsal gerçeklik arasındaki bu ilişkiyi Diken ve Laustsen (2010) şu şekilde ifade etmişlerdir: "Sinema hayattır ve hayat da sinemadır, ikisi de birbirinin hakikatini anlatır." Bu bakımdan İranda sinema, İran'ın siyasal dinamiklerini, toplumsal dönüşümlerini ve kültürel kodlarını yansıtmak için etkili bir araç olagelmiştir. Pour'un da belirtmiş olduğu üzere; "İran'in, toplumsal değişimlerini filmlerinden takip edebiliriz. Filmlerde toplumun sosyal, kültürel, siyasal ve ekonomik değişimleri bulunabilinir" (2007). Bu yönüyle sinema filmleri toplumda cereyan eden siyasi, kültürel ve iktisadi dönüşümlerin izleyici tarafından okunmasına ve analizine imkan tanır.

Bu çalışma kapsamında; İran'da devrim öncesi ve sonrası dönemin toplumsal olgu ve olaylarını kavrayabilmek ve açıklayabilmek maksadıyla sinema filmlerinden faydalanılmıştır. Devrim öncesi ve sonrası olmak üzere iki farklı dönemde İran toplumunun gerçekliklerini irdeleyen iki film üzerinden, ilgili dönemlere dair çıkarımların ortaya konması amaçlanmıştır. $\mathrm{Bu}$ amaç doğrultusunda, filmleri incelenmek üzere sanat anlayışları ile kendilerinden sonraki yönetmenleri etkilemiş ve uluslararası festivallerden çeşitli ödüllerle dönmüş iki isim olan Sohrab Şehide Sales ve Mecid Mecidi seçilmiş olup; devrim öncesi dönemin toplumsal ve siyasi dinamiklerini anlamak adına Sohrab Şehide Sales'in "Cansız Tabiat" filmi, devrim sonrasının toplumsal ve siyasal atmosferine işık tutmak adına ise Mecid Mecidi'nin "Serçelerin Şarkısı" filmi analiz edilmiştir. Çalışma için Sohrab Şehide Sales ve Mecid Mecidi'nin seçilmesi; her iki yönetmenin filmlerinin de üretildikleri dönemin toplumsal meselelerini ele alıyor olması nedeniyle incelenmeye esas alınmıştır.

Sohrab Şehide Sales ve Mecid Mecidi sinema anlayışlarının inşasında, yaşadıkları coğrafyanın sosyokültürel koşullarının ve siyasi ikliminin yanı sıra; yönetmenlerin eğitimi, dünya görüşü, ideolojisi, yaşamı algılayışı ve duyuşu da etkili olmuştur. Her iki yönetmen de yaşadıkları dönemin sosyo-politik ortamından etkilenmiş olup; yaşadıkları olayları ve gözlemlerini beyazperdeye yansıtmıştır.

Sohrab Şehide Sales 1960'ların sonlarında ortaya çıkan “İran Yeni Dalga” akımın önemli isimlerindendir. Şehide Sales “Viyana ve Paris'te film eğitimi aldıktan sonra, Kültür Bakanlığı tarafından yönetmesini istenilen etnografik kısa dizileri çekmek için İran'a geri dönmüştür. Bu dönemde Şehide Sales, ezilmiş ve hakları ellerinden alınmış marjinal hayatlara odaklandığı ilk iki filmi ile 'İran Yeni Dalga' sinemasının mihenk taşı kabul edilmiştir" (Sohrab Shahid Saless: Exiles, 2017) Şehide Sales, bu başarısıyla döneminde "Genç Çehov" (Pour, 2007) adıyla anılmıştır.

Sohrab Şehide Sales, filmlerini devrim öncesinin kültür-sanat ortamında üretmiştir. Yapıtlarıyla İran sinemasının uluslararası alanda tanınırlı̆̆ına önemli katkılarda bulunmuş olan Şehide Sales, geliştirdiği "uzun çekim-uzun metraj ve amatör aktörlere dayalı, duygusallıktan uzak ve gözlemci bir hikaye anlatıcllığını benimseyen" (Haghighat ve Rahgozar) sinema anlayışı ile, kendinden sonraki birçok yönetmeni de etkilemiştir. Şahide Sales'in İran sinemasına yeni bir açılım getirdiğini Dabashi (2004) şu şekilde açıklar: 
“Söhrab Şehide Sales, Yek İttifak-1 Sadeh (Basit Bir Hadise, 1973) ile onun hemen arkasından çektiği Tabi'at-e Bijan (Cansız Tabiat, 1975) adlı filmleriyle gerçekliğe bakış konusunda yepyeni bir açılım getirecektir. Bu öncü filmlerle birlikte, gerçekliğin edilgen biçimde belgelenmesi yöntemi, yeni realizm anlayışına damgasını vurdu. Dili son derece anlaşılır olan, gerçeğin maskesinin şimdiki zaman karşısındaki gücüne yapılan vurgu aracılığıyla düşürülmesini esas alan Şehide Sales, sinemasının itici gücü sayılabilecek bu anlayış, daha sonra Kiyarüstemi ve Mahmelbaf'in 1980'ler ve 1990'larda çektiği en iyi filmlerde etkisini gösteren önemli öğelerden birine dönüşecektir. "

1974 yılında hükümetin artan baskı ve sansürüyle karşı karşıya kalan Şehide Sales, daha önceden festivallerde ödül kazanmış olduğu Almanya'ya gitmiştir. Yönetmenin "uzun tatil" diye adlandırdığı bu dönem, 25 yıl sürmüştür. (Sohrab Shahid Saless: Exiles, 2017).

Mecid Mecidi ise 1990'lı yıllar itibariyle film üretmeye başlamış olup; günümüz İran sinemasının gelişimine önemli katkılarda bulunmuş yönetmenler arasında yer alır. Orta sınıfa mensup bir aileden gelen Mecid Mecidi, filmlerini devrim sonrasının siyasal ikliminde üretmiştir. 1979 devrimi sonrasında “...üniversiteler kapatıldığında ise Mecidi, arkadaşlarıyla "Hozeye Honer ve Endişeye Eslam-i” adında sanat merkezini açmışlar ve bu merkezde tiyatro faaliyetlerine devam etmiştir" (Yaghmoorala, 2013). Sanata olan ilgisini çocukluk yıllarına dayandıran Mecidi, bu ilginin zaman içerisinde tutkuya dönüşmesini ve sinemayla yolunun kesişmesini şu sözlerle anlatır:

"13 yaşımdan beri sinema başta olmak üzere görsel olan her şeye ilgim vardı. Çok film izlerdim, arkadaşlarımla tiyatro oynuyordum. Dramatik Sanatlar Fakültesi'nde Tiyatro Bölümü okudum. Tiyatro, bir süre sonra devam ettiremeyeceğim bir hal alınca sinemaya başladım. İlk önce oyuncu olarak birkaç filmde rol aldım. Sonra birkaç kısa film yaptım. Daha sonra uzun metraj filmlere başladım. Sinema benim için yoldur, misyondur. Düşüncelerimi anlatmak ve duygularımı konuşturma fırsatı veren bir alan. Sorunları, dertleri sinema yoluyla başka insanlara anlatıyorum. Entelektüel kesim dahil halkın geneline hitap ediyorum. Zor ama, amacım iki gruba da aynı anda seslenip etkilemek. İnsanları, doğasına ve iç dünyasındaki saflığa geri dönmesi için hikayelerimle desteklemek istiyorum." (Kızmaz, 2017).

Mecidi bu amaçla, filmlerinde İran'ın kültürel yapısını, toplumsal değerlerini ve ülkede önemli bir sorun teşkil eden yoksulluğu konu edinmiş, bu doğrultuda pek çok eser vermiş bir yönetmendir. 1992 yılındaki ilk filmiyle sinemada adını duyurmuş olan Mecidi, "1999 yapımı Cennetin Çocukları filmiyle Oscar yarışına dahil olan ilk İranlı yönetmen olmayı başararak, En İyi Yabancı Film kategorisinde ilk beşe girmiştir " (Ferahmend, 2007). Bu sayede hem dünya çapında tanınırlık kazanmış, hem de İran sinemasının uluslararası festivallerdeki görünürlüğünün artmasına öncülük etmiştir.

Sonuç olarak bu çalışma kapsamında, dönemlerinin toplumsal yapısına ve siyasal dinamiklerine dair gerçekçi bir tablo çizen "Cansız Tabiat" (Sohrab Şehide Sales, 1975) ve "Serçelerin Şarkısı" (Mecid Mecidi, 2008) adlı filmler analiz edilmiştir. İncelenmek üzere seçilen bu filmlerin; çekildikleri dönemlerin toplumsal koşulları göz önünde bulundurularak, konuları ve işlenişleri bakımından karşılaştırılmaları ve aralarındaki benzerliklerin ve farklılıkların ortaya konması amaçlanmıştır.

\section{Devrim Öncesi; İran Siyasi ve Toplumsal Yapısı}


İran'ın siyasi tarihinde 1921 yılında gerçekleşen askeri darbe ile iktidara gelen Rıza Han, 1925 yılında taç giyerek kendisini şah ilan etmiştir. Böylece, İran' da 1979 yılına kadar devam edecek olan Pehlevi Hanedanlığı dönemi başlamış oldu. Bu tarihten itibaren, Rıza Şahın, modernleşme çabaları merkezi yönetimi güçlendirmeye yönelikti. Rıza Şah'ın "modern ordu, hükümet bürokrasisi ve hukukun üstünlügü" (Der-Grigorian, 1998) üzerine kurduğu yeni düzenin Elliot (2012) göre iki temel amacı söz konusuydu:

“... öncelikle Meclis içerisinde disiplinli bir çoğunluk oluşturacak güçlü, Şah yanlısı bir parti kurmak ve bu yolla radikal reform tekliflerinin kanunlaşmasını güvence altına almak ve ikinci olarak geniş ölçekli üyelik yoluyla subayların, memurların ve halkın arasından bazı unsurların Şah'ı desteklemek üzere örgütlenmesini ve mobilize edilmesini sağlamak."

Yeni hanedanlığı sağlamlaştırmak adına atılan adımların ardından 1927 yılında köklü bir sekülerleşme ve merkezileşme programı başlatan Rıza Şah, yeni politikalarını uygulamaya koyabilmek için orduyu devreye sokmuştur.

Rıza Şah; İran'ı modern bir devlete, İran halkını ise modern bir topluma dönüştürmek adına iktisadi, hukuki ve kültürel nitelikte pek çok reformu hayata geçirmiştir. Bu dönemde ulusal bir banka kurulmuş, İran'ın tamamını baştanbaşa geçecek demiryolunun inşaatına başlanmış, karayolları ağı genişletilmiştir. Benzer şekilde, bu dönemde, sanayileşme ve Batılı devletlerle iktisadi ilişkiler alanında bir takım yenilikler yapılmaya çalışılmıştır: "Sanayileşme teşvik edilip bir miktar maddi yardımla desteklenmiştir. Ayrıca Avrupalı tüccarlarla imalatçlara hukuki ve iktisadi avantajlar sağlayan kapitülasyonlar 1928 yılında kaldırılmıştır. Ticaret ve sanayi tekelleri kurulmuştur" (Garthwaite, 2011). Bu şekilde uygulamaya konan ekonomik politikalarla, İran ekonomisi güçlendirilmesi hedeflenmiştir; ancak bu iktisadi çabalar halkın genelinde memnuniyetsizliğe yol açmıştır. Mali ve askeri reformlara ağırlık verilen bu dönemde (1927-29), “... belirli aralıklarla eyaletler boyunca muhtelif kasabalarda ve şehirlerde ve farklı kırsal kesimler arasında devletin bu yeni programına karşı muhalefet hareketleri patlak vermiştir. Genelde bu hareketler şehir merkezlerinde orta derecedeki ulema ve loncalar tarafından, taşrada ise kıdemsiz kabile hanları ve ağalar tarafından yönetilmiştir" (Cronin, 2010).

Kamusal alanda da birçok reformu hayata geçiren Rıza Şah, 1928 yılında "uluslararası tartıların kullanılması, Kaçar döneminden kalma lakap ve unvanların kaldırılması, içki ve kumarın yasaklanması ve kıyafet düzenlemesi" (Metin, 2011) hakkındaki kanunları yürürlüğe koymuştur. Bu dönemde k1lık-kıyafet için getirilen düzenleme ile ilgili olarak, Abrahamian (2009) şunları ifade eder:

"Aşiret giysilerinin ve geleneksel giyimin yanısıra, Kaçarlarla birlikte kullanılmaya başlamış fes gibi başlıkları yasaklamıştı. Bütün yetişkin erkeklerin devlette -'kayıtlı' din adamları dışında- Batı tarzı pantolon ve ceket giymeleri ve 'Pehlevi başlı̆̆ı' adı verilen önü siperli şapka takmaları gerekiyordu."

Rıza Şah'ın iktisadi, kültürel ve kamusal alanlarda uygulamaya koyduğu modernleşme ve sekülerleştirme politikaları, toplumun farklı kesimleri tarafından farklı şekillerde algılanmıştır. Kamusal alandaki yeniliklere yönelik farklı toplumsal kesimlerde ortaya çıkan ikircikli tutumu, Cronin (2010) şu şekilde ortaya koyar:

“Kıyafet Kanunu zaten Batı modasına ayak uydurma sürecinde olan şehirli, eğitimli, modern unsurlarca memnuniyetle karşılanmıştı. Ancak aynı kanun kendi rollerinin ve kimliklerinin 
küçümsendiğini hisseden eyalet mollaları ve kabile mensuplarınca ve yeni kıyafet gereçlerini temi etmekten aciz olmanın yanı sıra yeni giyim tarzına kültürel olarak bir anlam veremeyen ülkenin her yerindeki fakirlerce büyük bir öfkeyle karşılanmıştır."

Rıza Şah'ın farklı toplumsal ve kültürel alanlara yönelik modernleşme ve sekülerleşme politikaları, İkinci Dünya Savaşı'na kadar sürmüştür. İkinci Dünya Savaşı ile değişen koşulların ardından Rıza Şah, 1941 yılında tahtını oğlu Muhammed Rıza Şah'a devretmiştir. Böylelikle Rıza Şah'ın “ordu”, "hükümet bürokrasisi” ve "hukukun üstünlüğ̈̈" aracilığıyla hüküm sürdüğü devir sonlanmış, 1979 yılına kadar sürecek olan Muhammed Rıza Şah dönemi başlamıştır. Babasının merkeziyetçi ve "otokrat" yönetimiyle karşılaştırıldığında bu yeni dönem pek çok açıdan daha demokratik özellikler göstermiştir. Dolaysıyla, "Rıza Şah'ın otoriter yönetimini gören halk, Muhammed Rıza Şah döneminde siyasetle daha çok ilgilenmiş, birçok siyasi parti ve grup etrafında örgütlenmiştir" (Gökdemir, 2014).

Muhammed Rıza Şah yönetiminin ilk aylarında, sol grupların etrafında birleştiği Tudeh Partisi kurulmuştur. Şah'ın iktidarına karşı olan Tudeh Partisi'nin eylemleri sınırlı kalmış olsa da, partinin bu süreçte toplumda yarattığı entelektüel ve kültürel etkiler kalıcı nitelikte olmuştur. Tudeh Partisi, Abrahamian ifadesiyle, “İran'a kitlesel politikayı, kitle katılımını, parti hücre ve kollarını, parti konferans ve kongrelerini, parti gazetelerini, politbüroları, merkez komite ve kitlesel örgütlenme anlayışını getirmiştir" (Abrahamian, 2009).

Muhammed Rıza Şah yönetimine karşı bir diğer muhalif tepki, 1950'li yılların başında Muhammed Musaddık liderliğindeki İran milliyetçilerinden yükselmiştir. 1951-1953 yılları arasında başbakanlık görevinde bulunan Musaddık, mecliste Şah'ın batılılaşma politikalarına karşı çıkarak halkın desteğini kazanmıştır. Musaddık tarafından başlatılan millileştirme hareketi doğrultusunda Şah, bir süre ülkeyi terk etmek zorunda kalmıştır. Fakat milli cephenin bu hamlelerine karşılık Muhammed Rıza Şah, 1953 yılında Amerika destekli bir askeri darbe ile Musaddık hükümetini devirmiş ve “bundan sonraki çeyrek yüzyıl boyunca, İran'ı diktatör olarak yönetmiştir" (Goldschmıdt ve Davıdson, 2008).

Amerika'nın desteklediği darbe sayesinde yönetimi tek elde toplayan Muhammed Rıza Şah, askeri güçler ve benzeri vasıtalarla halk üzerinde bir baskı kurmuştur. Musaddık darbesini takip eden diktatörlük döneminde Şah, İran'da ekonomik, sosyal ve idari alanlara yönelik politikaları uygulamaya koymuştur. Muhammed Rıza Şah, 1961 yılında "Ak Devrim” olarak adlandırılan reform programını uygulamaya geçirmiştir. Bu programın amacını Kaya şu şekilde sıralamıştır; "Köylünün toprak reformu yoluyla kurtarılması ve ağa köylü ilişkilerine son verilmesi, seçim kanununda temel değişiklikler yapılması, cehalete son vermek amacıyla eğitim kurumlarının oluşturulmasıdır. Toprak reformu ve tarımı geliştirme projeleri finanse etmek amacıyla devlet elindeki endüstrinin halka devredilmesi, ülke ormanlarının millileştirilmesi ve sanayi işçilerinin net kâra ortak olmasıdır" (2013). Program içeriğindeki maddelerine ilişkin, Kerim'in (1980) yorumu şu şekildedir:

“Devrim temelde batılılaşmayı, kadınlara serbest ilişki kurma haklarını, modern toplum organizasyonlarını, İslam'a karşı batılı kurumların tesisi ve monarşinin gölgesinde kapitalizme geçiş gibi esaslara dayandığından otoriter bir yönetimi kaçınılmaz kılıyordu."

Ancak, modernleşmeyi hedefleyen bu reform paketinin halkın talepleri dikkate alınmadan yürürlüğe konmuş olması, Muhammed Rıza Şah'a yönelik kitlesel bir muhalefetin önünü açmıştır. Gündoğan (2010) ortaya çıkan bu muhalefet durumunu, nedenlerini ve muhalif zümreleri şu şekilde açıklar: 
“Bu dönemde büyük ölçüde toprağa bağlı bir yaşam sürdüren geleneksel kitlelerin, toprak reformu marifetiyle yine geleneksel yapılarının parçalanması, ittifaklarının çözülmesi ve yaşam tarzlarına müdahale edilmesi, büyük toprak sahiplerini, ulemayı, esnaf, çiftçi ve tüccarı kızdırmıştır."

Muhammed Rıza Şah'ın otokratik tutumu toplumun farklı kesimlerinin eleştirilerine yol açmıştır; ancak bu süreçte altı çizilmesi gereken nokta, rejime karşı muhalefetini açıkça ortaya koyan gruplar arasında, ilk defa, dini sınıf Humeyni önderliğinde muhalif kesimler arasında yer almıştır. Humeyni'nin Şah rejimine yönelik muhalefeti büyük ölçüde "toplumun artan sekülerleşmesi, modernite projelerinin agresif bir şekilde yayılması, İslamcı düşüncelerin ve doktrinlerin hızla düşüşü, Marksist ve materyalist düşüncelerin dünya tarihindeki yaygın varlığı ve Şah'ın bunaltıcı otoritesi" (Chelkowski ve Dabashi, 2018) gibi sebeplerden kaynaklanmıştır. Bunun sonucunda Şah, toplumdaki diğer muhalif tepkilerde yaptı̆̆ gibi, Humeyni'nin muhalefetini de sert bir şekilde bastırma yoluna giderek, Humeyni'yi tutuklatmıştır. Humeyni'nin tutuklanması, halk nezdinde büyük protestolara ve infiale sebebiyet vermiştir. Halkın bu büyük infiali karşısında "ağır silahlarla teçhiz edilmiş ordu birlikleri Tahran'da halkın üzerine ateş açmış ve çok sayıda kişi öldürülmüştür. Bu olaylar İran tarihine '15 Hordad' ismiyle geçmiştir" (Kerim, 1980). Dolayısıyla, Humeyni'nin tutuklanması, İran'da İslami hareketlerin başlangıcını tetiklemiştir. Toplumun sert muhalefeti karşısında Şah çözümü Humeyni'nin ülke dışına sürgün edilmesinde bulmuştur.

İran ekonomisi, 1973 yılındaki Arap-İsrail Savaşı ile Araplar tarafından uygulanmaya başlayan petrol boykotlarından olumlu yönde etkilenmiştir. Böylece, ülkenin ekonomik durumunun iyileşmesi, Şah'ın merkezi iktidarının daha da güçlenmesini sağlamıştır. Bununla birlikte Şah; hanedanına bağlı bir aristokrasiyi yerleştirmeye çalışırken, mecliste kendisine yakın isimlere yer vererek ve hükümete geniş yetkiler tanıyarak, kontrol mekanizmasını yaygınlaştırmıştır. Şah'ın ve çevresindekilerin ekonomik bakımdan güçlenmesi, bir kez daha halkın tepkisini toplamıştır. Bu dönemde ülke gelirleri artmış olmasına rağmen, toplumun içinde yaşadığı ekonomik koşullar kötüleşmiştir. Toplumda ortaya çıan bir denge problemine işaret eden, Saray (1999) Şah'ın bu uygulamaları ile ilgili; "ülkede dengeyi sağlayacak bir sosyal ortam yaratılmamıştır. Şah ve ailesine sadık bir avuç sivil-asker zümre çok iyi imkânlarla hayatlarına devam ederken, milyonlarca İranlı fakir bir hayat sürmeye başlamıştır" ifadelerini kullanır. Tüm bunlar; ülke genelindeki Şah'a yönelik hoşnutsuzluğun çoğalmasına sebep olmuştur.

$\mathrm{Bu}$ döneme genel olarak bakıldığında, Pehlevi hanedanlığı döneminde hayata geçirilen modernleşme ve sekülerleşme politikalarının, temelde merkezi yönetimi güçlendirmeye hizmet ettiği söylenebilir. Söz konusu politikalar karşısında muhalif bir tavır alan tüm gruplar, rejim tarafından sert müdahalelerle susturulmuştur. Bu durum, askeri zümreye ve üst toplumsal kesimlere hizmet eden Şah ile halk arasındaki ilişkiyi zayıflatmış ve böylece yönetimle halk arasında ciddi bir kopukluk ortaya çıkmıştır. Dolayısıyla, toplumdaki farklı ideolojik kesimler farklı zamanlarda iktidara karşı muhalif tutumlarını sürdürmeye devam etmişlerdir. Şah ise, toplumun muhalif kesimlerine yönelik sert müdahalelerini sürdürmekte ısrarcı olmuştur. Toplumun farklı kesimlerinde aynı anda yükselen bu muhalif tepkiler, 1970'li yılların sonuna gelindiğinde radikal bir kimliğe bürünmüş ve sonuçta Şah rejiminden koparak yeni bir rejimin yaratılmasını arzulayan bir kitlenin ortaya çıkmasına yol açmıştır. 


\section{Devrim Sonrası; İran Siyasi ve Toplumsal Yapısı}

Humeyni'nin 1 Şubat 1979 tarihinde İran'a dönüşü ve ardından Pehlevi hükümdarlığının sona ermesi ile devrim sürecinin tamamlanması, İran siyasi tarihindeki en önemli kırılmalardan biridir. Bu kırılma ile birlikte, devrim sonrasında siyasal, sosyal, ekonomik ve kültürel açıdan yeni bir döneme girilmiştir. İran'da yeni düzenin tesis edilmesi amaciyla Mehdi Bazargan başbakanlığında geçici bir hükümet kurulmuştur. Geçici hükümet ilk olarak bir referandum gerçekleştirmiş, bu referandum sonucunda Şahlık rejimi kaldırılarak yerine İran İslam Cumhuriyeti ilan edilmiştir. Böylece İran'da "İslami düzenin kurulma adımları, monarşinin yerine İslam Cumhuriyeti'nin geçmesini onaylayan referandum ile başlamıştır" (Cleveland, 2008).

Yeni düzenin kurumsallaşması adına, yasama-yürütme-yargı organları ve diğer kurumların yetkilerini de belirleyen, yeni bir anayasa hazırlanmıştır. Bu yeni düzende siyasal ve sosyal anlamda en kapsamlı yetkiler, anayasanın 5. maddesinde yer alan "Halkın ekseriyetinin kendisini Rehber bildikleri ve kabul ettikleri, adil, takva sahibi, devrini iyi bilen, cesur, idareci ve tedbirli bir fakihin uhdesindedir" (Anasaya, 1980) ifadeleriyle, Velayet-i Fakih'e verilmiştir. Ordu ve mahkemeler, gerçekleşen Devrimi korumak üzere yeniden düzenlenmiştir. Devrim sonrası yapılan ilk cumhurbaşkanlığı seçimlerinde Ebul Hasan Beni- Sadr cumhurbaşkanı olarak seçilmiştir. 1980 yılında Irak'ın tek taraflı olarak İran'a saldırması ile başlayan Irak-İran savaşı ise, devrimin kurumsallaşması sürecini olumlu yönde etkilemiştir. Savaş şartları "Humeyni'ye milliyetçilikle İslam arasında bir sentez yapma, aynı zamanda da muhalefeti devrimin ve İran'ın düşmanları safına atarak gözden düşürme fırsatını vermiştir" (Khosrokhavar ve Roy, 2000).

Irak ile savaşın sürmekte olduğu 1980'li yıllarda, İran iç politikasında devrimin toplumsal, siyasal ve kültürel olarak her bakımdan yaygınlaştırılması hedefiyle hareket edilmiştir. $\mathrm{Bu}$ doğrultuda ilk olarak devrim esasları ile ihtilafa düşen cumhurbaşkanı Ebul Hasan Beni-Sadr, görevinden alınmıştır. Ardından, 1981 yılında gerçekleştirilen ikinci cumhurbaşkanlığ seçimleri ile "Muhammed Ali Recai Cumhurbaşkanı olmuştur. Muhammed Ali Recai'nin suikastla öldürülmesinden sonra Seyyid Ali Hamaney, cumhurbaşkanı olarak seçilmiştir. Böylece, Hamaney ile birlikte bu makam ulemanın eline geçmiştir" (Üstün, 1999). Ali Hamaney'in seçilmesi ile birlikte, İran'da toplumsal yapının ve kamusal düzenin İslami prensiplerle uyumlu hale getirilmesi maksadıyla, "Kültür Devrimi" adı altında çeşitli uygulamalara başlanmıştır. Kültür Devrimi kapsamında; toplumsal yaşam, kılık-kıyafet, eğitim, müfredat, basın gibi farklı alanlarda bir takım değişikliklere gidilmiştir. Devrim sonrasında en görünür değişimler, kadınların kamusal alandaki varlıklarına yönelik uygulamalar ile yaşanmıştır. Bu bakımdan, Pehlevi döneminin modernleşme ve batılılaşma politikalarına karşılık, "devlet memurları dâhil bütün kadınlar boy giysileri giymesi ve başlarını hicab denen örtüyle örtmesi yönünde değiştirilmiş. Ayrıca Muhammed Rıza Şah'ın çıkardığı aile koruma yasaları değiştirilmiş, kadınların boşanma davası açma, çocuğunu alıkoyma, evliyse okula devam etme ve hukuk, tıp, mühendislik gibi konularda öğrenim görme hakkını kaybetmiştir" (Clevelend, 2008). Hicab (örtünme) uygulaması ile birlikte değişen görünüme ve hicabın değişen niteliğine dair, Sancar (2016) şu ifadeleri kullanır:

“Devrim sırasında siyasal muhalefetin birliğinin ve dayanışmasının bir simgesi ve Şah rejiminin karşısında olmanın bir göstergesi olan örtünme-hicab, devrimin hemen ertesinde yeni rejime gösterilen desteğin bir simgesi haline dönüştü. Kadınların İslami geleneklere 
uygun olarak örtünmüş olması bir yandan siyasal yaşamda İslamcıların gücünün bir göstergesi olurken diğer yandan da yeni kurulmakta olan İslami rejimin ne ölçüde desteklendiğinin bir belirtisi haline geldi"

Devrim sonrası devam eden bu süreç üniversitelere de yansımış olup, üniversiteler uzun bir süre kapatılarak denetim sağlanana kadar açılmamıştır. Bu süreçte, rejime muhalif olabileceği düşünülen "Solcu yada hükümet karşıtı olarak görülen binlerce öğrenci üniversiteden atılmıştır" (Parsa, 2004). Birçok alanda yansımaları olan Kültürel Devrim'in etkisi, basın ve kültürel yaşamı da büyük oranda etkilemiştir. Bu dönemde rejimin izlediği basın-yayın ve kültür siyaseti sonucunda ortaya çıkan durumu Abrahamian'ın (2009) ifadeleriyle şu şekilde özetleyebilmek mümkündür:

"...gazetelerden kitaplara, radyo ve televizyon yayınlarına kadar pek çok şeye sansür uygulamış, monarşiyi ve laik kahramanları öven anlatımları yok etmek için kitapları yeniden yazdırmıştır. Avrupalı isimlerin kullanılmasını yasaklamış, halka açık alanlarda eski krallara ait ne varsa kaldırtmıştır. Safeviler tarafından İsfahan da yaptırılmış Şah Camii'nin adı İmam Camii olarak değiştirilmiştir. Cadde ve meydanlarda Pehlevileri çağrıştıran adlar değiştirilmiştir"

Devrim sonrasındaki değişim süreci, 1989 yılında Humeyni'nin vefat edişi ile sekteye uğramıştır. Aynı dönemde, Irak ile İran arasında devam etmekte olan savaş da sona ermiştir. Böylelikle İran'da; siyasi, toplumsal ve ekonomik bakımdan yeni bir sürece geçiş yapılmıştır. Vefatının ardından Humeyni'nin yerine Hamaney gelirken, bu dönemde Ali Ekber Haşimi Rafsancani cumhurbaşkanı seçilmiştir. Rafsancani'nin görevde bulunduğu iki uzun dönem (1989-1997) boyunca, savaş sonrası yapılanmalar üzerine çalışılmıştır. Bu dönemde İran 'Onarım Cihadı' adı verilen ekonomik politikalar eşliğinde yönetilmiştir.

Ağırlığı ekonomik politikalara veren Rafsancani'nin sosyal politikaları, halkın değişmekte olan talep ve beklentilerini karşılamakta yetersiz kalmıştır. Humeyni'nin vefatı ardından ve Irak ile sekiz yıl sürmüş olan savaşın yarattığı sosyo-ekonomik tahriplerin bir sonucu olarak, halk, adalet ve özgürlüğün tesis edildiği bir alana ihtiyaç duymaya ve olumlu bir gelişmeye yönelik beklenti içinde olmaya başlamıştır. Bu dönemde halk, isteklerini ve beklentilerini ifade etmek için sesini yükseltmeye başlamıştır. Toplum tabanından yükselen memnuniyetsiz söyleme, İranlı entelektüellerin eleştirileri de eklenmiştir. Bu dönemde devrimi destekleyen "Abdülkerim Suruş gibi süreçte etkin rol alan bazı isimler, yavaş yavaş eleştirel duruşlarını göstermeye, farklı düşüncelerini dillendirmeye başlamışlardır" (Onat, 2013). Muhsin Kadivar, Muhammet Müctehit Şebestari, Said Haccariyan, Abdullah Nuri ve Ekber Genci gibi isimlerin de aralarında bulunduğu bu entelektüeller; devrimin gerçekleştirilmesinde bizzat rol almış ve devrime sadakatlerini sunmuş kişilerdir. Ancak süreç içerisinde devrimin yaygınlaşması adına çeşitli alanlarda yapılan değişikliklere yönelik muhalif bir tavır benimseyerek, yeni çözüm yollarına dair önerilerde bulunmaya başlamışlardır. Bu muhalif entelektüellere İranlı yönetmenlerden Muhsin Makhmalbaf'ı örnek veren Dabashi (2008), konuya ilişkin şunları aktarir:

“İslam Cumhuriyeti'ne yönelik bu iç muhalefet döneminin en dikkat çeken isimlerinden biri de, dünya çapında tanınmış bir yönetmen, romancı ve toplumsal eylemci olan Muhsin Makhmalbaftır. Bu muhalif grubun diğer üyeleri gibi oda ilk zamanlarda kendini bütünüyle 
İslam devrimi davasına adayarak, İslam Cumhuriyeti'nin propaganda mekanizması içinde yer almış, fakat sonraları bu hareketten koparak rejime muhalif tavır almıştır."

İran toplumunu çevreleyen bu atmosferde, 1997 yılında beşinci cumhurbaşkanlığ seçimleri gerçekleştirilir. Seçim sürecinde Hatemi, "özgürlük”, "halk egemenliği”, “hukuki yönetim”, "sivil toplum" ve "medeniyetler arası diyalog" gibi kavramlar çerçevesinde vaatlerde bulunur. Hatemi, seçim kampanyası sırasında seslendirdiği ilke ve değerlerle hem rejimin içinde bulunduğu krizi atlatması için arayış içinde olan etkili kişi ve kesimleri, hem de rejime karşı kayıtsız olan ve oy kullanmayı da bu yüzden pek düşünmeyen geniş kitleleri, özellikle de gençler ve kadınları kendi yanına çekmiştir (Oğuz ve Çakır, 2000). Böylelikle, vaatleri halkın beklentileri ile örtüşen Hatemi, 1997 yılında oyların çoğunluğunu alarak İran'ın beşinci cumhurbaşkanı seçilmiştir. Hatemi'nin kazanması ile ilgili olarak, Oğuz ve Çakır "halkın radikallik ve muhafazakârlığa karşı ılımlılığı tercih ettiğini göstermiştir. Çünkü Hatemi, İran siyasi sahnesine hâkim olan bıktırıcı İslami söylemden farklı bir söylem, farklı bir gündem, farklı bir bakış açısı geliştirebilmiştir" (2000) açıklamasında bulunur.

1997-2005 yıllarını kapsayan iki dönem boyunca cumhurbaşkanı olarak görevi yapmış olan Hatemi, iç ve diş politikada birçok reformu hayata geçirmiştir. Hatemi döneminde sivil toplum kuruluşlarının ve siyasi partilerin kuruluşlarına olanak sağlanmıştır. Ayrıca anayasanın gereklilikleri arasında yer almasına rağmen bu döneme kadar uygulanmamış olan yerel seçimler ilk kez gerçekleştirilerek, demokratikleşme yönünde önemli bir adım daha atılmıştır. Bireysel özgürlükleri ve basın özgürlüğünü tesis etmek amacıyla; gazete, dergi gibi basılı yayınlarda, sinemada ve sahne sanatlarında ifade özgürlükleri esnetilmiştir. Gençlerin taleplerine öncelik verilerek, kültürel faaliyetlerde ve sporda önemli ilerlemeler kaydedilmiştir. Kadın hakları konusunda ise özgürleştirici uygulamalara başlanmış olup; sosyal, siyasal ve kültürel alanlarda kadınlara yeni haklar tanınmıştır.

Cumhurbaşkanlığı döneminde Hatemi tarafından yürütmüş olan sosyal politikaların başarısı, ekonomik alanda yakalanamamıştır. Bu dönemde "küresel piyasa ekonomisi"nin benimsenmesi ile birlikte özelleştirme politikaları devreye girmiştir. Ancak bu özelleştirme politikaları, İran'da artmakta olan yoksulluk sorunu için etkili bir çözüm getirmemiştir. Hatemi' nin ekonomik politikalarının göz ardı ettiği “yoksullaşmış kentli ve köylü alt sınıf 2005 yılında cumhurbaşkanlığı seçimlerinde tepkilerini göstermişlerdir. Doğrudan yoksul ve imtiyazsız kesme hitap eden radikal bir muhafazakâr olan Mahmud Ahmedinejad reform hareketinin temelini sarsan bir zafer kazanmıştır" (Dabashi, 2008). Sonuç olarak, ekonomik eşitlik umudu ile İranlılar oylarını muhafazakârlardan yana kullanmıştır. Ahmedinejad döneminde kamusal alana yönelik baskının ve denetimin yeniden oluşturulmasına çalışılmıştır. Bu dönemde "cinsiyet ayrımı, kadınların giymesi zorunlu kıyafet şekli, medya ve film endüstrisinin kontrolü ve denetimi" (Önder, 2013) yeniden gündeme gelmiş, sıkı bir denetim ve sansür mekanizması devreye sokulmuştur. Dolayısıyla bu; siyasal, sosyal, ekonomik ve kültürel alanların yeniden muhafazakârların hâkimiyetine girmeye başladığı bir dönem olmuştur.

Genel olarak devrim sonrası İran'ın siyasal ve toplumsal dinamiklerine bakıldığında, siyasi gücün sağ (muhafazakar) ve sol (reformist) tutumlar arasında devamlı olarak yer değiştirdiği görülmektedir. Devrim sonrası dönem süreçlere ayrıldığında, yeni düzenin kurumsallaştırılmasına yönelik çalışmalarla geçen 1979-1989 dönemi "birinci cumhuriyet" olarak kabul edilir. Humeyni liderliğindeki bu dönem, 1989'da Humeyni'nin vefatının 
ardından farklı bir yöne evrilir. Söz konusu tarihte Humeyni'nin vefatı sosyo-politik olguları değiştirirken, Irak-İran savaşının sonlanması ise sosyo-ekonomik olguları değiştirmiştir. "İkinci cumhuriyet" olarak adlandırılan dönem ise, cumhurbaşkanı Rafsancani'nin politikaları etrafında şekillenmiştir. Bu yeni dönemde toplumun belli bir kesiminin memnuniyetsizliğinin artması ve yönetimden beklentilerin yükselmesi doğrultusunda, aydınların ve entelektüellerin eleştirilerini açık bir şekilde ifade etmeye başladığı görülür. İran siyasetine yeni bir yön veren bu durum, 1997 yılında "üçüncü cumhuriyet"e giden yolun önünü açmıştır. 1997' deki cumhurbaşkanlığı seçimlerini kazanan Hatemi; siyasal, sosyal ve kültürel alanlarda reformist politikalara yönelmiştir. Bu doğrultuda halkın talep ettiği adalet, eşitlik ve bireysel özgürlükler yönünde olumlu değişimler yaşanmıştır. Ancak üçüncü cumhuriyet dönemi, İran siyasetinin değişken dinamiklerine bir örnek olarak, 2005 yılında Ahmedinejad'in seçilmesiyle sona ermiştir. Böylelikle İran'da, kontrol yeniden muhafazakârların hâkimiyetine geçmiştir. Bu süreç ise 2013 yılındaki cumhurbaşkanlığ seçimlerini Ruhani'nin kazanması sonucunda reformist kesimin yeniden güç kazanmaya başlaması ile sonuçlanmıştır. Bu değişken geçişlerin; İran yakın siyasi tarihinde ekonomik, sosyal, siyasal ve kültürel birçok alanda halen devam etmekte olan derin etkileri olmuştur.

\section{Cansız Tabiat Film Çözümlemesi}

Yönetmenliğini ve senaristliğini Sohrab Şehide Sales'in üstlendiği "Cansız Tabiat” (Tabi'at-e Bijan) filmi, yaşlı bir demiryolu işçisinin yaşantısını perdeye aktarırken, alt metniyle 1960'ların İran'ındaki toplumsal, ekonomik ve siyasal sorunlara değinir. 1960'lı yıllarda İran, Muhammed Rıza Şah'ın hükümdarlığındadır. Söz konusu dönem modernleşmeye ve batılılaşmaya verilen önemin arttığ1, devlet politikalarının bu doğrultuda yürütüldüğü bir dönem olup; Şehide Sales, bu batılılaşma politikalarının bürokrasiye ve sıradan bir aileye nasıl yansıdığına dikkat çeker.

Film, 70'li yaşlardaki Muhammed Sardari'nin iş ve ev arasında kendini tekrar eden günlük yaşantısı üzerine kuruludur. Demiryolu işçisi olan Muhammed'in görevi, tren geçişlerine göre demiryolu bariyerini kaldırıp indirmektir. Hikâyenin üzerinden ilerlediği Muhammed Sardari'nin eşi de, filmin başlıca karakterlerindendir. İzleyici, Muhammed'in ev işleri ve kilim dokuması ile meşgul olan eşini, film boyunca ev içerisindeki günlük yaşantısı üzerinden takip eder. Filmin akışı içinde önemli yer tutan günlük sıradan işler, ailenin asker olan oğlunun iki günlüğüne ziyarete gelmesi ile sekteye uğrar ve bu şekilde izleyici, aile içi ilişkileri gözlemleme fırsatı bulur. Ailenin düzenini değiştiren başka bir olay ise, Muhammed'in, demiryolu memurlarının denetimi ardından yaşı sebep gösterilerek emekli edilmesidir. Emekliye ayrılan ve yerine genç bir memur atanan Muhammed'in bu duruma karşı çıkarak bürokratik bir çözüm arayışında bulunması, anlatı içerisinde ön plana çıkan noktalardan biridir. Bu arayış; Muhammed'in durumu kabullenip eşyalarını bir at arabasına yükleyerek, evini ve tekdüze yaşamını terk etmesi ile son bulur.

"Cansız Tabiat" filmiyle, Sohrab Şehide Sales, bir demiryolu işçisi ve onun ailesi üzerinden İran'a ilişkin birçok toplumsal meseleyi irdeler. Bu bakımdan filmde, aile bireyleri arasındaki ilişkiler ve davranış biçimleri dikkat çekmektedir. Film, Muhammed'in demiryolu bariyerini indirdiği sahne ile başlar. Uzun yıllar demiryolu işçisi olarak çalışmış olan Muhammed'in eski giysisi ve ayakkabıları, yalnız ve yorgun hali izleyiciye sunulur. Tren raylarının yanında eski bir bekleme kulübesi vardır ve Muhammed vaktinin büyük bir bölümünü bu kulübede ve evinde geçirir. 
Filmde eşi de Muhammed'in bu tekdüze yaşamını onunla paylaşır. Kadın karakterin adı bilinmemekle birlikte; izleyici onu film boyunca ev içerisindeki hali, sakin davranışları ve eski giysileri ile görür. Eşi ve eve gelen erkek misafirler, kadının ev sınırları dışındaki yaşam ile tek bağlantısıdır. Ailenin asker olan oğlu da bu misafirlerden biridir. Genç adam, ailesini iki günlüğüne ziyarete gelir. Anne ve oğulun ilk karşılaşması, alışılmadık bir şekilde olur. Her iki taraf da mesafeli davranır ve herhangi bir sevgi ya da özlem belirtisi göstermez. Devamında, genç adamın annesi ile diyaloğu, ihtiyaçları doğrultusunda gerçekleşir. Annesinden paltosunun kopan düğmesini dikmesini ister. Kadın, yaşlılığına ve iyi görmeyen gözlerine rağmen bu ihtiyacı karşılamak için hazırdır. Filmde ataerkil aile yapısının kadını ev işlerinden ve ev içi bakım hizmetinden sorumlu tuttuğuna, daima kadına sorumluluk ekseninden yaklaştığına ve kendisine atfedilen toplumsal cinsiyet rollerine uyması yönündeki beklentiye dikkat çekilir. Kadın film boyunca ev işleri ile meşgulken görülür ve bu işler olağan karşılanmakta olup, kadının eşi ve oğlu tarafından takdir edilmez. Sales'in kadına yüklenen toplumsal roller ve sorumluluklar konusundaki eleştirel tavrı filmine yansır. Bu bakımdan; kadının yalnızca ev işlerinden ve ev içi bakımdan sorumlu olmadığı, kadının farklı işler yaparak ev ekonomisine katkı sağlayabileceği düşüncesi, filmde, kadın karakterin kilim dokuması ile işlenir. Bu şekilde ataerkil aile yapısında kadın için ev içiyle sınırlandırılmış olan çizgiler az da olsa genişlemiş olur.

Aile içi ilişkilerde, bireyler arasında mesafeli ve soğuk bir tavır dikkat çeker. Aynı sofrada yemek yemeleri, vakitlerini aynı yerde geçirmelerine rağmen aile üyelerinin birbirlerine davranışlarında bir yakınlık gözlenmez. Söz konusu mesafe, oğulları evden ayrılırken annebabanın, karşılarında oğullarından ziyade bir asker duruyormuşçasına hazırda beklemeleri ile pekişir. Bu soğuk ve resmî hava, annenin, oğlunun arkasından pencereden hüzünle baktığ görüntü ile kırılır.

Ataerkil aile yapısında ikili ilişkilerde sıkça rastlanan bu keskin sınırlar; özellikle iş bölümünde ve ev yaşantısında gözlemlenir. Bu bakımdan Şehide Sales, ailenin ev içindeki yaşantısını izleyiciye tüm detaylarıyla sunmaya çalışır. Kadın ve erkeğin ayrı yatıyor olması ve kadın yer yatağında yatarken erkeğin eski bir karyolada yatması film boyunca tekrar edilerek gösterilir. Aile içerisinde kadın ve erkeğin yapmakla yükümlü olduğu işler, toplumsal cinsiyete dayalı roller çerçevesinde belirlenmiştir. Demiryolu işçisi olan Muhammed, zamanının çoğunu, gelecek trenleri bekleyerek geçirir. Filmde Muhammed'in ev içi işlere ve eşinin ihtiyaçlarına karşı duyarsız tutumu dikkat çeker. Muhammed'in eşi ise ev işlerinden sorumludur ve erkek kamusal alanda çalışırken, kadının ev içi işlerden sorumlu olması ile ataerkil toplumsal düzenin ve ataerkil aile yapısının gerekleri yerine getirilir. Her iki karakter de kendisi için belirlenmiş olan görev sınırlarının dışına çıkmaz. Kadının dışarı ile bağlantısı eşi üzerinden gerçekleşir. Filmdeki diyaloglar, kadının aile içindeki konumunu ortaya koyar niteliktedir.

Film mekânsal olarak merkezden uzakta bir köyde geçmektedir. Birkaç haneden oluşan bu köyde Muhammed ve eşi, demiryolu yakınında bir evde yaşar. Eski ve harabe bir görünüme sahip bu ev, bakımsız bahçesi ile dikkat çeker. Yönetmen filmde evin içerisinden birçok detay sunar. Ev tek odalıdır ve oda, hem mutfak hem de yatak odası olarak kullanılır. Evin az sayıda ve eski olan eşyaları; sandalye, masa ve bir saatten ibarettir. Filmde saat, aile için önemli bir yere sahiptir. Ailenin zaman kavramı ile tek bağını bu saat kurmaktadır. Aile için önem taşıyan bir diğer öge ise ailenin dış dünya ile bağlantısını sağlayan trendir. Şehir merkezinden gelen 
tren, aileye ekmekle birlikte çeşitli haberler de getirir. Ailenin düzeni bu trenin geliş-gidiş saatleri üzerine kurulmuştur. Şehide Sales'in filmde bir çalar saat ve gelen-giden tren üzerinden kurduğu zaman ve ihtiyaç olgusu, döneme yönelik bir eleştiri niteliği taşır.

Filmde, Muhammed Rıza Şah döneminin önemli sorunlarından biri olarak ekonomik durum konu edinilmiştir. Şah'ın ve çevresinin bu dönemdeki aşırı ve lüks harcamaları, halkın hoşnutsuzluğuna sebep olmuştur. İran'da mevcut ekonomik sıkıntılar, ilk sahneden son sahneye kadar, bir ailenin ekonomik sorunları paralelinde işlenmeye devam eder. Demiryolu işçisi Muhammed kamu görevlisi olarak, yetersiz koşullarda ve düşük bir ücretle çalışır. Muhammed'in ekonomik beklentilerine, izleyici, ilk olarak kendisini denetlemeye gelen memurlarla arasındaki diyaloglar aracılığıyla tanık olur. Bu diyaloglarda denetim memurunun söylediklerini önemsemeyen Muhammed "Benim yılbaşı ikramiyesine ne oldu?" (00:07:40) sorusu ile asıl kaygısını belli eder. Aile bütçesine katkı sağlayan diğer kişi Muhammed'in eşi olup, film boyunca kilim dokuma makinesinin önünde görülen kadın, ev ekonomisine kilim dokuyarak katkıda bulunur. Ancak demiryolu işçiliği ve kilim dokuma uğraşları, ailenin yoksulluğuna çare olacak yeterlilikte değildir. Bu gerçeklik, filmde Muhammed'in eşinin dokuduğu kilimler için alıcı geldiğinde karakterler arasında geçen diyaloglarla aktarılmıştır. Şehirden gelen adam kilimin istediği motife sahip olmamasından dolayı "Kimse artık bu tür halıları almıyor. Kimse bu modeli istemiyor. Bu bize göre değil. Bu havada bu kadar yolu geldik. İşte 2200 riyal." (00:43:57) ifadelerini kullanır. Muhammed ise, "Zarar ediyoruz. Gece gündüz çalışıyoruz, bu adil bir alışveriş değil." (00: 44:29) sözleri ile eşinin emeğini korur. Ancak alıcının "Kimse sizi satmaya zorlamıyor. Size kalmış." (00:44:35) sözleri karşısında Muhammed'in elindeki paraya uzun uzun baktığı sahne ile kapitalist düzende bireyin emeğinin değersizleştirilmesine vurgu yapılır. Şehide Sales filminde işçiyi, emeği ve kadınların hakkını Muhammed'in "adil bir alışveriş değil" sözleri ile savunur.

Filmin bürokrasiye yönelik bir eleştiri barındırdığı görülür. Muhammed Rıza Şah'ın siyasi yapılanmasını "bürokrasi ve ordu" üzerine kurmasını, Sohrab Şehide Sales'in filminde bazı olgular ve durumlar üzerinden eleştirilir. Yönetmenin eleştirisi, ilk olarak, ailenin asker olan oğlunun eve iki günlügüne ziyarete gelmesi ile görülür. Bu ziyaret esnasında aile bireyleri arasındaki diyaloglar üzerinden ordu ve askeri şartlar izleyiciye aktarılmaya çalışılırken, ailenin, oğullarının yorgun ve zayıf görünümünden yakınması dikkat çeker. Bu dönemde ordunun ve askerliğin yüceltilmesine rağmen, askerlik şartları iyileştirilmemiştir. Ziyarete gelen genç adamın, ailesine armağan olarak getirebildiği şey yalnızca iki meyve olmuştur. Askerin tüm imkânsızlı̆̆ı, zayıf ve çelimsiz görünüşü karşısında Muhammed; “Kemikleri sayılıyor" (00:57:11) ifadesini kullanır ve eşi, ona biraz para vermesini ister.

Bürokrasiye yönelik ikinci eleştiri ise, bir gün gelen trenlerden biriyle Muhammed'e emeklilik bildiri mektubunun ulaşması ile aktarılır. Okuma yazma bilmeyen Muhammed mektubu anlamaz ve mektubu getiren gençten onu okumasını talep eder. Dönemin şartlarına bakıldığında, Pehlevi döneminde eğitime ve toplumsal yaşama yönelik yenilikçi politikaların uygulandığı görülür. Ancak bu politikalar modernleşmeyi ve batılılaşmayı hedeflemektedir. Kamu hizmetinde bulunan Muhammed'in okuma yazma bilmemesi, bu politikaların toplumun ihtiyaçlarını karşılama noktasındaki aksaklığına işaret eder. Mektup, Muhammed'in yaşından dolayı emekliye ayrıldı̆̆ını bildirir. Muhammed "emekli" sözcüğünü hayatında ilk defa duymuştur. Şaşkın bir biçimde "emekli" sözcügü ile ne denmek istediğini anlamaya çalışır. Karşısındaki genç ise "Bundan sonra hayatın keyfini çıkar" 
(01:02:09) ifadesiyle ona durumu açıklar. Şehide Sales toplum için "emeklilik" kavramının yabancı olduğuna dikkat çeker. Filmde emekliliğin anlamının batılı bir düşünüşle "hayatın keyfini çıkartmak" olduğu ifade edilir. Muhammed ise bu durumu "İşten çıkarıldım" (01:03:32) şeklinde ifade eder. Böylelikle, filmde, Pehlevi döneminde uygulanan modernleşme ve batılılaşma politikalarının halkta ne şekilde yankı bulduğuna dikkat çekilir.

Muhammed'in emekli edilmesinin ardından yerine genç bir görevli atanır. Bu durum karşısında eşi, Muhammed'e “Git şikâyet et. Kalacak bir yerin olmadığını söyle." (01:03:50) diyerek öneride bulunur. Muhammed bu fikrin işe yarayacağını umarak, bir trene ilk defa yolcu olarak biner ve şehre gider. Şehirde ilk önce demiryolu müdürlüğüne giden Muhammed, burada patronunu görmek istediğini söyler ve problemini anlatmaya çalışır. Fakat kimse kendisine yardımcı olmaz. Burada çalışan görevliler onu farklı bir yere yönlendirir. Şehide Sales bu şekilde, kamu kurumlarında işlerin akışındaki aksaklığı izleyiciye gösterir. 30 yıldan uzun süre demiryolu işçiliği yapmış olan Muhammed birey olarak dikkate alınmazken, ona gönderilmiş emekli kâğıdı muhatap alınır. Muhammed, gittiği ikinci kurumda daha sert bir tavırla karşılaşır. Müdürün odasındaki iki kişi arasında "Şimdi Amerika'da, çok zengin oldu. Orada dükkânı var" (01:27:20) konuşmaları dikkat çeker. İkili arasındaki bu diyalog batılılaşmanın bireyler üzerindeki tesirine işarettir. Bir görevli emekli kâğıdına bakarak Muhammed'e, "Hayırlı olsun, emekli olmuşsun. Şimdi git" (01:26:53) der ve arkadaşına dönerek onunla muhabbetini sürdürür. Muhammed'in kendini ifade etmek için 1srarlı bekleyişine karşılık, odadaki görevlilerin onu görmezden gelerek aralarındaki sohbeti sürdürmesi dikkat çeker. Görevliler için Muhammed'in varlığ 1 ve yokluğu bir fark yaratmaz. Bu esnada çay ikramı yapan çalışan dahi, Muhammed'in varlığını önemsemez.

Otuz yıl kamu hizmetinde bulunmuş olan Muhammed'in, bir emekli bildiri mektubu ile tüm düzeni bozulmuştur. Bireyin hayatına emeklilik kavramını getirmiş olan sistem, onun ihtiyaçlarını sigorta altına almamıştır. Muhammed'in film boyunca tanık olunan alışkanlıkları ve yaşantısı, bir at arabasına sı̆̆dırılmıştır. Sonuç olarak Sohrab Şehide Sales, "Cansız Tabiat" filmiyle, dönemin siyasi ve sosyal yapısına dair gerçekleri, izleyiciye bir ailenin günlük yaşantısı üzerinden sunmuştur. Filmde ekonomik sorunlar, toplumsal cinsiyet eşitsizlikleri, halk ve bürokrasi arasındaki kopukluk, söz konusu dönemde uygulanan yenilikçi politikaların halka ve bireylere ulaşmaması gibi konulara dikkat çekilmektedir.

\section{Serçelerin Şarkısı Film Çözümlemesi}

Mecid Mecidi "Serçelerin Şarkısı" (Avaze Gonjeshk-ha) adlı filmde, deve kuşu çiftliğinde çalışmakta olan Kerim ve ailesi üzerinden İran'da devrim sonrası dönemin toplumsal, siyasal, ekonomik ve kültürel gerçeklerine değinir. Aile içi ilişkilere, çalışma koşullarına ve bireyin toplumdaki varlığına vurgu yapan film; bir ailenin günlük yaşantısının paralelinde, İran'da devrim sonrasının toplumsal meselelerine ilişkin bir okumaya da imkân tanır.

Ailesi ile birlikte kırsalda yaşayan Kerim karakteri, bir deve kuşu çiftliğinde çalışır. Bir gün, bakımından sorumlu olduğu deve kuşlarından birinin Kerim'in ihmali nedeniyle kaçması, Kerim'in işten atılmasına sebep olur. Kızının bozulan işitme cihazını tamir ettirmek üzere Tahran'a giden Kerim, burada motorla taksicilik yapmaya başlar. Geçim sıkıntısı, işitme cihazının tamiri için gerekli olan para ve borçları dolayısıyla bu işi yapmaya başlayan Kerim, Tahran sokaklarında birçok toplumsal gerçeğe tanıklık eder. İzleyici, Kerim karakterinin motoruyla taksicilik yapmaya başlaması ile değişen hikâye üzerinden; bireytoplum ilişkisine 
dair bir çözümleme yapma imkânı bulur. Olayların akışı Kerim'in bir gün kaza sonucu sakatlanması ile tekrar değişir. Bunun ardından sağlığına uzun bir süre kavuşamayan Kerim'in iç dünyası, aile ilişkileri, karakterlerin duygu-düşünce yapıları, geçim sıkıntısı ve yoksulluk ön plana çıkmaya başlar. Film Kerim'in bakımından sorumlu olduğu, kaybolan deve kuşunun bulunması ile son bulur.

"Serçelerin Şarkısı" adlı filminde, Mecidi, toplumdaki yoksulluk ve işsizlik sorununa dikkat çeker. Filmde Kerim karakteri, ailesinin geçimini deve kuşu çiftliğinde çalışarak sağlamaktadır. Burada düşük bir ücretle ve sigortasız çalıştırılan Kerim, bir gün bakımından sorumlu olduğu bir deve kuşunun çiftlikten kaçmasının ardından işten atılınca, borçlarını ödeyemez hale gelir ve ailesinin ihtiyaçlarını karşılamakta zorlanır.

İran'da işsizlik oranının yüksek oluşu; birçok sosyo-ekonomik sorunu beraberinde getirmektedir. Filmde izleyici bu gerçekliğe, Kerim'in işsiz kalması, ailesinin olumsuz ekonomik koşullar altında genel ihtiyaçlarını karşılamakta zorlanması ve işsizliğin yol açtığ diğer sorunlarla mücadelesi ile şahit olur. Ailenin en belirgin sorunu, yetersizliklerden kaynaklanan, sağlığa ulaşımdır sorunudur. Kerim, kızının bozulan işitme cihazını tamir ettirmeyi bir çözüm olarak düşünür fakat doktor, yeni bir cihaz satın alması gerektiğini söyler. İşsiz olan Kerim için yeni bir işitme cihazının fiyatı oldukça yüksektir. Film boyunca kızının işitme cihazı için çeşitli çözümler arayan Kerim'in bu çabası işe yaramamış, işitme cihazı için gerekli olan parayı hiçbir zaman toplayamamıştır.

"Serçelerin Şarkısı" filminde önemli bir yer tutan bir diğer konu İran'ın görünür en büyük sorunlarından bir olan ekonomik sorunlardır. Kerim'in işten çıarılmasının ardından gelişen olaylar, ailesinin temel ihtiyaçlarını karşılamakta güçlük çekmesine ve özellikle işitme cihazı konusunda çaresizlik hissine kapılmasına yol açar. Bu bakımdan Mecidi'nin, ekonomik sorunların birey, aile ve toplum üzerindeki olumsuz etkilerini filmine taşıdı̆̆ı söylenebilir.

Filmde aile içi ilişkiler, bireylerin duygu dünyası ve iş bölümü mekânsal olarak ev üzerinden izleyiciye sunulur. Ev; mutfak ile birleşik tek ve geniş̧ bir odadan oluşur. Bu geniş oda ailenin günlük yaşamını sürdürdüğü, yemek ve uyku ihtiyaçlarını giderdiği tek alandır. Filmde eve dair sıklıkla öne çıkan öge televizyon antenidir. Anten aynı zamanda bir ekonomik ve sınıfsal göstergedir. İzleyici önce Kerim'i, televizyonun daha net ve iyi göstermesi için evin çatısında uğraşırken görür. Kerim'in uğraşları sonucunda televizyonun görüntüsünün iyileşmesi ile çocukların sevinci dikkat çeker. Televizyon anteninin temsil ettiği ekonomik koşullar, Kerim'in motor taksiciliği yaptığı sırada, bir yolcusunun inşaat alanındaki hurdalar arasından bir anten bulması ile değişir. Kerim'in hurdadan bulduğu televizyon antenini evin çatısına yerleştirmesi ile ailenin sosyo-ekonomik statüsünün değişmeye başladığına tanık olunur. Bu durum, komşularının çatılarındaki televizyon antenlerine dönük bir şekilde gösterilir. Kerim Tahran'a yaptığı yolculukların her birinde hurdadan birçok malzeme almaya başlar. Kısa bir süre sonra evin bahçesinde; eski kapılar, dolaplar, demir ve tahta yığınları oluşur. Kerim tüm bu eşyaları evin ihtiyaçları doğrultusunda "yeni” kabul ederek değiştirir. Şehirde hurda olarak görülen bu malzemeler, Kerim'in evi için yeni olarak kabul görür. Malzemelerin bir bölümünü komşularına satan Kerim'in bu hali, birbirini tekrar eder şekilde sunulur.

Filmde ev içerisine dair detaylara da yer verilir. Genişlik ve ferahlık hissinin hâkim olduğu evde; samimi bir atmosfer mevcuttur. Aile bireyleri arasındaki diyaloglarda; fedakârlık, merhamet ve sevgi hisleri ön plana çıkar. Ev içerisinde ailenin ikili ilişkileri, günlük yaşantısı 
ve çocukların arkadaşları ile oyunları izleyiciye aktarılır. Aile içi ilişkilerde özellikle Kerim'in işitme engelli kızının eğitimine verdiği önem ön plana çıkar. Kerim'in kızının bozulan işitme cihazı yerine yenisi almak için gösterdiği çaba, kızının yakın bir zaman diliminde gerçekleşecek sınavları için kaygılanmasından ve öğreniminin aksamasından duyduğu endişeden kaynaklanır. Bu bakımdan Kerim'in kız çocuğunun eğitimi konusundaki duyarlılığı dikkate değerdir. Mecidi kız çocuklarının eğitimi hususundaki duyarlılığını, kızının eğitimini önemseyen Kerim karakteri üzerinden izleyiciye sunmuş ve eğitimin önemini filminde vurgulamıştır.

Filmde aile bireyleri arasında öne çıkan bir diğer isim ise; anne kimliği ile Nergis'tir. Eve ilişkin sorumlulukları yerine getirirken ailesiyle ilişkileri ve komşularıyla yakın diyaloğu dikkat çeken Nergis; tüm bu ilişkilerde 1lımlı, fedakar ve merhametli bir tavır sergilemektedir. Filmde aile ilişkilerinde söz konusu olan bu olumlu atmosfer, iş bölümüne de yansımaktadır. Aile içi iş bölümü keskin sınırlarla ayrılmamakta olup; filmin ilk sahnelerinde ev içi işlerinden sorumlu olan Nergis, Kerim'in sakatlanmasının ardından ev ekonomisine katkı sağlayan bir kimliğe bürünür. Filmin sonunda evinin geçimi, ev içi işleri ve çocukların sorumlulukları kadın karakterin yükümlülüğündedir

"Serçelerin Şarkısı" filminde Mecid Mecidi'nin, kırsalda ve kentte yaşayan bireyler arasındaki sosyal, ekonomik ve kültürel farklılıklara dikkat çeker. Kerim karakterinin Tahran'da motor taksiciliği yaptığı süreçte karşılaştığı yolcular ile aralarında geçen diyaloglar; modern ve geleneksel değer yargılarını irdeler. Kırsal bölgede yaşayan, doğulu yaşam tarzına sahip, eğitim ve ekonomik statüsü düşük kesimi temsil eden Kerim karakterinin karşısına; kentte yaşayan, batılı yaşam tarzına sahip, eğitim ve ekonomik statüsü yüksek bireyler yerleştirilmiştir.

Kerim, Tahran'ın kalabalığı, gürültüsü ve binaların görüntüsünün ihtişamı karşısında hayranlık duyar. Şehrin yoğun trafiği, kalabalık dükkân ve caddelerdeki kentlilerin aceleci ve telaşlı hallerine yer verilir. Kerim'in Tahran sokaklarında motor taksiciliği yaptığı sırada, motosiklete binen farklı yolcular ile izleyiciye her defasında yeni bir hikâye yansitılır. Filmde, kentli bireyin değer yargıları, her yolcu ile birlikte yeniden sorgulanır. Kerim, her yolculuk sonunda, yolcuların ücretin ne kadar olduğuna dair sorusuna "Ne kadar verirsen" (00:26:25) şeklinde yanıt verir, işine bir değer biçmez. Kentli birey ise bunun karşılığını, bazen olumlu bazen olumsuz şekilde verir. Yolcular arasında ücreti fazlasıyla veren ve ücreti verdiğini iddia ederek Kerim'i zor durumda bırakanlar da olur. Bu bakımdan filmde kentli bireyin kaybettiği değer yargıları, dünyevi olana düşkünlüğü ve maddiyata verdiği değer, Kerim'in karşılaştığı tavirlar yoluyla eleştirilir.

Mecidi, kırsalda ve kentte yaşayan bireyler arasındaki farklılıkların manevi boyutuna da dikkat çeker. Bu sorgulama, yolcuların telefon konuşmaları ve Kerim'e yönelik tavırları ile aktarılır. İzleyici, Tahran'da bir gün, yolculuk sırasında yolculardan birinin telefondaki; “Tahran'da falan değilim, aslında Meşhed'deyim, Türbenin yakınlarında. Merak etme senin için de dua edeceğim. Baksana 'hacı' benim için bir şey yapar mısın?" (00:37:32) sözlerine tanık olur. Bu telefon konuşmasında, kentli bireyin manevi sömürüsü ve etik anlayışı sorgulanır. Bu sorgulamalar farklı yolcular ile devam eder. Yolcusunu bıraktığ 1 yerde Kerim'den, taşınma aşamasında hamallık yapması da istenir. Yolcu, "Merak etme daha fazla öderim, paranı alacaksın" (00:46:43) sözleri ile Kerim'i para karşılığında kendi menfaati için kullanmak istediğini belli eder. Kerim bu tavra "Bana paramı verin de ben yoluma gideyim, ben anlamam 
ki bu işten. Ben hamal değilim, paramı istiyorum" (00:47:20) sözleriyle karşılık verir. Kentli bireyin manevi sömürü ve faydacılık üzerine kurulu ikili ilişkileri, filmdeki diyaloglar aracılığıyla eleştirilir. Filmde kırsalda yaşayan Kerim'in ikili ilişkilerinin ise, yardımlaşma ve fedakârlık üzerine kurulu olduğu görülür. Kerim'in çiftlik işinden atıldığı gün evinde pişen yemeği komşuları ile paylaşması, bu duruma bir örnektir. Kırsalda ve kentte yaşayan bireyler arasındaki bu sorgulamada Mecidi, kentin karmaşası içerisindeki kentli bireyin tutum ve değer yargıları karşısına, kırsal yaşamın samimi ve sade yaşamını koymuştur. Bu açıdan Mecidi, filminde kırsalda ve kentte yaşayan bireyler arasındaki diyaloglar ile İran'ın geleneksel ve modern kesimi arasındaki farklılıkları izleyiciye aktarmıştır.

Sonuç olarak Mecidi, İran toplumsal yaşamına ilişkin işsizlik, yoksulluk ve sağlık hizmetlerindeki problemler gibi konuları filmine taşırken; bireyin günlük yaşantısını, telaşlarını, duygu ve düşüncelerini de izleyiciye tüm yönleriyle de aktarmaya çalışmıştır.

\section{Sonuç: Film Karşılaştırması}

Sohrab Şehide Sales ve Mecid Mecidi, İran sinemasının gelişmesine katkı sağlamış önemli isimler arasındandır. Aynı coğrafyada farklı dönemlerde yaşamış olan bu yönetmenler, İran'a dair birçok unsuru, kendi perspektifleriyle filmlerine taşımıştır. Sales "Cansız Tabiat" adlı filmini devrim öncesinde 1975 yılında, Mecidi ise "Serçelerin Şarkısı" adlı filmini devrim sonrası 2008 yılında çekmiştir. İki film arasında otuz yılı aşkın büyük bir zaman farkı bulunmasına rağmen; her iki film de yoksulluk, işsizlik gibi değişmeyen toplumsal sorunları, aile içi ilişkileri ve kadın sorunlarını işlemiştir. Bu bağlamda, her iki film de detaylarıyla incelendiğinde, aralarında bir takım benzerliklerin ve farklılıkların bulunduğu görülür.

Şehide Sales ve Mecidi, kameralarını sıradan insanların günlük yaşamına çevirmiştir. Her iki film de günlük yaşamda birey-toplum ve kişiler arası ilişkilere odaklanmaktadır. "Cansız Tabiat" ve "Serçelerin Şarkısı"; aile içi ilişkileri konu edinmeleri bakımından benzerliğe sahiptir. "Cansız Tabiat" filminde, aile içi ilişkiler, bireyin duygu-düşünce dünyası, çalışma koşulları, dönemin siyasi ve sosyoekonomik sorunları, demiryolu görevlisi Muhammed karakteri üzerinden anlatılır. Mecidi ise "Serçelerin Şarkısı" filminde aile içi ilişkileri, sıradan bireylerin günlük yaşantısını, kır-kent bireyleri arasındaki farklılıkları, dönemin sosyal ve ekonomik sorunlarını motor taksiciliği yapan Kerim karakteri üzerinden izleyiciye aktarmıştır.

"Cansız Tabiat" ve "Serçelerin Şarkısı" filmlerinde; kadın sorunları, kadının ev içi sorumlulukları ve aile bireyleri ile ikili ilişkiler ele alınmıştır. Her iki film de kadın karakterlerin günlük kıyafetleri, ev içindeki rutin işleri ve çocukları ile ilişkileri üzerinde durur. Şehide Sales ve Mecidi kadına dair konuları titizlikle işlemiş, filmlerindeki kadın karakterlere toplumsal hayata katılmaları bakımından önemli bir işlev yüklemiştir. Bu bakımdan, ataerkil bir toplum içerisinde kadının evin geçimine ekonomik açıdan katkı sağlaması önemli bir göstergedir. "Cansız Tabiat" filminde kadına ev içerisinde kilim dokumacılığ ile ekonomik statü kazandırılırken, "Serçelerin Şarkısı" filminde kadının tarlada çalışması ile ailesine ekonomik katkı sağladığı görülür. Ancak her iki filmdeki kadın karakterler, aile içi ve sosyal ilişkileri bakımından farklılık gösterir. "Cansız Tabiat" filminin kadın karakterinin yaşam alanı evin içidir. Filmde anne ve eş kimliklerine sahip kadına herhangi bir sevgi ve saygı gösterilmez. Kadının, anne kimliği, iki günlügüne ziyarete gelen oğlu ile ilişkisiyle yansıtılmıştır. Ancak anne-oğul ilişkisi ihtiyaç üzerine kuruludur. Bunun 
aksine "Serçelerin Şarkısı" filminde kadın, anne ve eş kimliği ile sevgi ve saygı görür. Kadının eşi ve çocukları ile ilişkisi, merhamet ve fedakârlık üzerine kuruludur. Ayrıca filmde kadının komşuları ile olan ilişkileri üzerinden sosyal yaşamına da yer verilir.

"Cansız Tabiat" ve "Serçelerin Şarkısı"; mekânsal özellikleri bakımından benzerlik gösteren filmlerdir. Her iki filmde de olaylar kırsal bölgede geçmekte olup, 'yoksulluk' olgusu, mekân üzerinden sunulmaktadır. Her iki filmde de ev eşyalarının sayıca az ve eski oluşu dikkat çeker. "Cansız Tabiat" filminde evin içerisinde bir saat, sandalye ve masa bulunur. Evin tek odası vardır ve burası, ailenin hem yemek hem uyku ihtiyaçlarını da karşıladığı mekândır. "Serçelerin Şarkısı" filminde ise ev büyük bir salondan oluşur. Bu salon aynı zamanda mutfağa bağlıdır ve ailenin günlük yaşamını, uyku ve yemek ihtiyaçlarını karşıladığı alan yine burasıdır. Mecidi mekân üzerinden ifade ettiği yoksulluk olgusunu ayrı bir boyuta taşımıştır. Filmde Kerim karakteri, Tahran'da çalıştığı günlerde çeşitli mekânlardan bulduğu hurda malzemeleri tamir etmiş ve evi için kullanmıştır. Kerim'in evindeki derme çatma eşyaları hurdalarla değiştirmesi, onun yoksulluğunun boyutlarına dair izleyiciye fikir verir.

"Cansız Tabiat" ve "Serçelerin Şarkısı" filmleri, çekildikleri dönemin mevcut ekonomik koşullarını yansıtmakta olup, filmlerde işsizlik ve yoksulluk problemi öne çıkan temalar arasındadır. Farklı dönemlerde yaşamış olmalarına rağmen, her iki yönetmen de İran'ın süregelen ekonomik sorunlarını filmlerinde konu edinmiştir. Yine her iki yönetmen de, işsizlik ve yoksulluk problemini, bireylerin psikolojik ve sosyal yaşamlarına olan etkileri üzerinden irdelemiştir. "Cansız Tabiat" filminde Muhammed karakterinin yoksulluğu mekânsal olarak evi, giyimi ve sosyal yaşamı üzerinden anlatılmıştır. Filmde irdelenen işsizlik problemi; Muhammed'in bir gün emekli edilmesi ve 30 yılı aşkın bir süredir yaşamakta olduğu mekânı terk etmek zorunda kalması ile anlatılır. "Serçelerin Şarkısı" filminde ise deve kuşu çiftliğinde çalışan Kerim, bir ihmal sonucunda işsiz kalmıştır. Geçim sıkıntısı, sağlık masrafları ve borçları; Kerim' in işsiz kaldığı bu süreçte maruz kaldığı sosyo-ekonomik sorunlar izleyiciye sunulur. Filmde işsizlikle ortaya çıkan yoksulluk hali, ev üzerinden anlatılır. Her iki film de İran'ın süregelen yoksulluk probleminin sıradan insanların günlük yaşantısına, duygu düşüncelerine olumsuz etkilerine yer verilmiştir.

Şehide Sales ve Mecidi, filmlerinde, sıradan insanın hikâyeleri ve problemleri üzerinden kendi dönemlerine dair eleştirilerde bulunmuştur. "Cansız Tabiat" filmi, Şehide Sales'in, dönemin bürokrasisine yönelik eleştirilerini barındırır. Bu filmde, Muhammed karakterinin emekli edilişini takiben gelişen olaylara ve Muhammed'in bürokrasi yoluyla bir çözüm arayışına yer verilmiştir. Çabaları yetersiz kalan Muhammed, sorununu dinleyecek ve onu dikkate alacak bir muhatap bulamamıştır. Şehide Sales, Muhammed karakteri ile yetkililer arasındaki diyaloglar yoluyla, bürokraside mevcut olan aksaklıklara dikkat çekmiştir. Muhammed'in oğlunun asker oluşu ve bunun etrafında gelişen olaylar ile ise; dönemin askeri şartlarına ve hükümetin 'ordu' politikasına yönelik bir eleştiri niteliği taşımaktadır. Mecidi'nin “Serçelerin Şarkısı” filmi ise, İran'ın sosyal ve ekonomik sorunlarına yoğunlaşmıştır. Filmde çiftlik işinden atılmasıyla Tahran sokaklarında motor taksiciliği yapmaya başlayan Kerim karakteri üzerinden kır-kent karşıtlığı ele alınmıştır. Kentte ve kırda yaşayan bireylerin değer yargıları arasındaki farklılıklara dikkat çekilen bu filmler, toplumdaki sosyal ve ekonomik sinıf farklılıklarına yönelik eleştirel bir dil kullanır.

Sonuç olarak Sohrab Şehide Sales ve Mecid Mecidi; İran'da birbirinden farklı dönemlerde, farklı siyasal ve sosyo-ekonomik koşullarda yetişmiş iki yönetmen olup, filmleri yoluyla 
toplumsal, siyasal ve ekonomik sorunlara dikkat çekmişlerdir. Her iki yönetmen de yaşadığ1 dönemin toplumsal meselelerine odaklanmış; filmlerinde sıradan bireylerin günlük yaşantılarını, telaşlarını, çabalarını, duygu ve düşüncelerini aktarmıştır. "Cansız Tabiat" ve "Serçelerin Şarkısı" isimli filmlerde de yoksulluk ve işsizlik, yoğun bir şekilde ön plana çıkan meseleler olup, aile içi ilişkiler gerçekçi bir yaklaşımla perdeye aktarılmıştır. Bu çerçevede, her iki filmin de değindiği sorunların, duygu ve düşüncelerin evrensel bir nitelik taşıdığ söylenebilir.

\section{Kaynakça}

Abrahamian, E. (2009). Modern İran Tarihi. (Çev. Dilek Şendil), İstanbul: Türkiye İş Bankası Kültür Yayınları.

Chelkowski, P., Dabashi, H. (2018). Bir Devrimi Sahnelemek. (Çev. Anıl Birer), İstanbul: The Kitap.

Cleveland, W. L. (2008). Modern Ortadoğu Tarihi. (Çev. Mehmet Harmanc1), İstanbul: Agora Kitaplı̆̆1.

Cronin, S. (2010). Yukarıdan Reform, Aşağıdan Direniş: İran'da Yeni Düzen ve Muhalifleri (1927-1929). (Der. Touraj Atabaki). Devlet ve Maduniyet Türkiye ve İran'da Modernleşme, Toplum ve Devlet. (Çev. Serhan Afacan). İstanbul: İstanbul Bilgi Üniversitesi Yayınları.

Dabashi, H. (2004). İran Sineması. (Çev. Begüm Kovulmaz, Barış Aladağ), İstanbul: Agora Kitaplığı.

Dabashi, H. (2008). İran: Ketlenmiş Halk. (Çev. Emine Ayhan), İstanbul: Metis Yayınları.

Der-Grigorian, T. (1998). Construction Of History: Mohammad-Reza Shah Revivalism, Nationalısm, And Monumental Architecture Of Tehran 1951-1979. Massachusetts Institute of Technology, Cambridge.

Diken, B., Laustsen, C. B. (2010). Filmlerle Sosyoloji. (Çev. Sona Ertekin), İstanbul: Metis Yayınları.

Elliot, M. (2012). Yeni İran ve Rıza Şah Döneminde Parti Sisteminin Sonu. (Der. Touraj Atabaki; Erik J. Zürcher), Otoriter Modernleşme Atatürk ve Rıza Şah Dönemler. İstanbul: İstanbul Bilgi Üniversitesi Yaymları.

Ferahmend, A. (2007). Son Dönem İran Sineması (Uluslararası Başarısı) Üzerine Perspektifler. (Ed.: Richard Tapper), Yeni İran Sinemasi; Siyaset, Temsil ve Kimlik, İstanbul: Kapı Yayınları.

Garthwaite, G. R. (2011). İran Tarihi Pers Imparatorluğu'ndan Günümüze.(Çev. Fethi Aytuna), İstanbul: İnk1lâp Kitapevi.

Goldschmıdt JR. A., Davıdson, L. (2008). Kısa Ortadoğu Tarihi. (Çev. Aydemir Güler),İstanbul: Doruk Yayımcilık.

Gündoğan, Ü. (2010). İran ve Ortadoğu. Ankara: Adres Yayınları.

İran İslam Cumhuriyeti Anayasası (1980). (Çev. Ömer Okumuş), İstanbul: Kayhan Yayınları.

Kaya, A. V. (2013). Karizmatik Liderlik ve Toplumsal Değişim. İstanbul: Hemen Kitap.

Kerim, M. (1980). İran İslam Devrimi. İstanbul: Düşünce Yayınları. 
Khosrokhavar, F., Roy, O. (2000). İran: Bir Devrimin Tükenişi. (Çev. İsmail Yerguz), İstanbul: Metis Yayınları.

Kızmaz, M. (2017). "Sinema Benim Yolum". Cumhuriyet Kültür. (Erişim Tarihi: 22.05.2020).

Metin, C. (2011). Emperyalist Çă̆da Modernleşme Türk Modernleşmesi ve İran (1800-1941). Ankara: Phoenix Yayınevi.

Oğuz, S., Çakır, R. (2000). Hatemi'nin İran'ı. İstanbul: İletişim Yayınları.

Onat, H. (2013). İran İslam Devrimi ve Şiîlik. e-makâlat Mezhep Araştırmaları,71(2),223-256.

Önder, E. (2013). İran'ın Nükleer Programının Analizi ve Türkiye. İstanbul: IQ Kültür Sanat Yayıncilik.

Parsa, M. (2004). Devlet, İdeoloji ve Devrim. (Çev. Alper Birdal, Nahide Özkan, Derya Göçer), İstanbul: İletişim Yayınları.

Pour, M. S. (2007). Tarihsel Gelişimin Işı̆̆ııda İran Sineması. İstanbul: ES Yayınları.

Sohrab Shahid Saless: Exiles. (2017). Goethe-Institut, London.

Sancar, S. (2016). Din, Siyaset ve Kadın. Ankara: Nika Yayınevi.

Saray, M. (1999). Türk İran İlişkileri. Ankara. Atatürk Araştırma Merkezi.

Şahid Saless, S., Haghighat M., \& Rahgozar. (1999). This Isn't Pessimism: Interview with Sohrab Shahid Saless. (Çev. Timothy S. Murphy), Discourse 21(1),175-180.

Ünalan, L., Gökdemir, A. (2014). İran Üzerine Notlar, İstanbul: Dezanj Yayınları.

Üstün, İ. S. (1999). İran İslam Cumhuriyeti Yönetim Biçimi-Humeyni'den Hamaney'e. İstanbul: Birleşik Yayıncılık.

Yaghmoorala, M. V. (2013). Majid Majidi Filmlerinde Sosyal ve Kültürel Anlatı Yapısı. Yayımlanmamış Yüksek Lisans Tezi, Ege Üniversitesi/Sosyal Bilimler Enstitüsü, İzmir. 